\title{
Machining Heat Induced Phase Transformation on the Surface Hardening Layer of High Strength Ferrous-Based Biomedical Stainless Steel
}

\author{
Chih-Yeh Chao ${ }^{1}$, Hsi-Jen Chiang ${ }^{2,3}$, Hsin-Ming Chung ${ }^{1}$, Keng-Liang $\mathrm{Ou}^{3,4,5, *}$ and Chih-Hua Yu ${ }^{3,4}$ \\ ${ }^{1}$ Department of Mechanical Engineering, Pingtung University of Science and Technology, PingTung 912, Taiwan, R. O. China \\ ${ }^{2}$ School of Dentistry, College of Oral Medicine, Taipei Medical University, Taipei 110, Taiwan, R. O. China \\ ${ }^{3}$ Research Center for Biomedical Devices and Prototyping Production, Taipei Medical University, Taipei 110, Taiwan, R. O. China \\ ${ }^{4}$ Research Center for Biomedical Implants and Microsurgery Devices, Taipei Medical University, Taipei 110, Taiwan, R. O. China \\ ${ }^{5}$ Gratuate Institute of Biomedical Materials and Tissue Engineering, College of Oral Medicine, Taipei Medical University, \\ Taipei 110, Taiwan, R. O. China
}

\begin{abstract}
The present study investigates the drilling characteristics of a high-strength $\mathrm{Fe}-8 \mathrm{Al}-30 \mathrm{Mn}-1 \mathrm{C}-1 \mathrm{Si}-3 \mathrm{Cr}$ (mass\%) biomedical alloy. After machining, a surface-hardening layer with a Vickers hardness number $\left(\mathrm{H}_{\mathrm{V}}\right)$ equal to 600 was observed. In addition, a $\gamma \rightarrow(\gamma+\kappa)$ phase transition was observed in the matrix and at the stress-induced twin boundaries of the surface-hardening layer. $\kappa$-phase carbides $\left((\mathrm{Fe}, \mathrm{Mn})_{3} \mathrm{AlC}_{x}\right)$ having an L' $1_{2}$ structure with the lattice parameter $a=0.375 \mathrm{~nm}$ were precipitated. Furthermore, the heat transfer coefficient of the present alloy was $0.083 \mathrm{cal} /\left(\mathrm{cm}^{2} \mathrm{~s}^{\circ} \mathrm{C}\right)$, which was lower than that of AISI 304 stainless steel, which was $0.098 \mathrm{cal} /\left(\mathrm{cm}^{2} \mathrm{~s}^{\circ} \mathrm{C}\right)$. The instantaneous cutting temperature of the present alloy was approximately $650^{\circ} \mathrm{C}$ during the machining process. It is believed that the formation of $\kappa$-phase carbides not only decreases the machinability of the present alloy, but also reduces the life of the cutting tool. These features could be useful in further understanding the relationship between the machinability and the microstructure of $\mathrm{Fe}-\mathrm{Al}-\mathrm{Mn}-\mathrm{C}$-based alloys, and thus provide information that would be allow these alloys to be used in biomedical and industrial applications. [doi:10.2320/matertrans.M2012107]
\end{abstract}

(Received March 21, 2012; Accepted June 1, 2012; Published July 25, 2012)

Keywords: iron-aluminum-maganese-carbon-silicon-chromium alloy, microstructure, phase transformation, machinability

\section{Introduction}

Austenitic Fe-Al-Mn-C alloys generally have optimal chemical compositions in the range Fe-(4.9-11.0)Al-(23.7$35) \mathrm{Mn}-(0.5-1.5) \mathrm{C}$ (mass $\%)$ and are formed by conventional casting with or without subsequent plastic deformation. ${ }^{1-5)}$ $\mathrm{Al}$ is added to promote resistance to corrosion and oxidation by the formation of a continuous protective layer of $\mathrm{Al}_{2} \mathrm{O}_{3}$ on the surface of the alloys. ${ }^{2,6,7)} \mathrm{Mn}$ is an austenite ( $\gamma$ phase) structure stabilizer, ${ }^{8}$ and carbon is an important strengthener. Using between $0.5-1.5$ carbon (mass $\%$ ) could lead to the coherent precipitation of fine $\kappa$-phase carbides $\left((\mathrm{Fe}, \mathrm{Mn})_{3} \mathrm{AlC}_{x}\right)$ with an $\mathrm{L}^{\prime} 1_{2}$ structure within the $\gamma$ matrix during the aging process. These precipitates have a strengthening effect. ${ }^{9,10)}$ Thus, they have been developed as a promising alternative to certain conventional biomedical $\mathrm{Fe}-\mathrm{Cr}-\mathrm{Ni}$-based stainless steels, as they replace $\mathrm{Cr}$ and $\mathrm{Ni}$ with lighter and cheaper elements such as $\mathrm{Al}$ and $\mathrm{Mn}$ without sacrificing desirable mechanical and biological properties.

Moreover, high-temperature corrosion and oxidation resistance as well as strength can be enhanced with metallic elements such as $\mathrm{Si}, \mathrm{Cu}$, Ti, Mo, Co and $\mathrm{Cr}^{3-5,11-14)}$ Of these, $\mathrm{Si}$ and $\mathrm{Cr}$ have been found to be the most effective in improving resistance to high-temperature corrosion and oxidation and environmental embrittlement. ${ }^{12,15)}$ As mentioned above, $\mathrm{Fe}-\mathrm{Al}-\mathrm{Mn}-\mathrm{C}-\mathrm{X}(\mathrm{X}=\mathrm{Si}, \mathrm{Cu}, \mathrm{Ti}, \mathrm{Mo}$, Co or $\mathrm{Cr}$ ) alloys have numerous attractive properties such as low density, high strength, superior ductility, good casting ability and good atmospheric corrosion resistance. ${ }^{12,16,17)}$ Hence, $\mathrm{Fe}-\mathrm{Al}-\mathrm{Mn}-\mathrm{C}-\mathrm{X}$ alloys are most suitable for the automotive, shipbuilding, and golf industries. Moreover, Chen et al. ${ }^{18)}$ have shown that a nanostructured oxide layer was formed

*Corresponding author, E-mail: klou@tmu.edu.tw on the Fe-Al-Mn alloy surface after electrical discharge machining; this layer could increase alloy biocompatibility. Thus, Fe-Al-Mn and Fe-Al-Mn-C-X alloys can also be developed as potential biomedical alloys.

Nevertheless, in the case of industrial and biomedical applications, the machinability of materials is significantly associated with the manufacturing process. Chao et al. ${ }^{19)}$ have reported that in the case of Fe-(4-12)Al-30Mn-1C (mass $\%$ ) alloys, produced after the tuning of different parameters, the surface roughness was in the range of $0.8-$ $2.7 \mu \mathrm{m}$. The feed rate has a significant effect on the surface roughness of these alloys. However, there is a lack of information about the drilling characteristics of Fe-Al-Mn$\mathrm{C}-\mathrm{X}$ alloys. Therefore, the purpose of the present study was to investigate the drilling characteristics of an $\mathrm{Fe}-8 \mathrm{Al}-$ $30 \mathrm{Mn}-1 \mathrm{C}-1 \mathrm{Si}-3 \mathrm{Cr}$ (mass $\%$ ) alloy with a pure $\gamma$ phase structure, and to elucidate and discuss the mechanism responsible for the difficulty encountered in machining the alloy, while providing information that could help in the use of such alloys in industrial and biomedical applications.

\section{Experimental Procedures}

An Fe-8Al-30Mn-1C-1Si-3Cr (mass\%) alloy sample was prepared in a vacuum induction furnace with a nitrogen atmosphere using AISI 1008 low carbon steel, 99.7\% pure electrolytic Al, 99.9\% pure electrolytic $\mathrm{Mn}$, pure carbon powder, pure silicon and pure chromium. After melting and stirring, the alloy was poured into investment casting molds (with a diameter of $80 \mathrm{~mm}$ and length of $300 \mathrm{~mm}$ ) preheated to $1150^{\circ} \mathrm{C}$ and its chemical composition, determined by inductively coupled plasma-atomic emission spectrometry, was found to be $\mathrm{Fe}-7.86 \mathrm{Al}-29.75 \mathrm{Mn}-0.95 \mathrm{C}-0.94 \mathrm{Si}-2.88 \mathrm{Cr}$ (mass\%). The obtained ingots were then homogenized at 
Table 1 The drilling parameters and AMN of holes that could be drilled in the alloys with various drill diameters.

\begin{tabular}{|c|c|c|c|c|c|c|c|}
\hline \multirow{3}{*}{ Drills } & \multirow{3}{*}{$\begin{array}{l}\text { Diameter } \\
(\mathrm{mm})\end{array}$} & \multicolumn{3}{|c|}{ Drilling parameters } & \multicolumn{3}{|c|}{ Trial materials } \\
\hline & & \multirow{2}{*}{$\begin{array}{l}\text { Cutting } \\
\text { velocity } \\
(\mathrm{m} / \mathrm{min})\end{array}$} & \multirow{2}{*}{$\begin{array}{c}\text { Feed } \\
\text { rate } \\
(\mathrm{mm} / \mathrm{rev})\end{array}$} & \multirow{2}{*}{$\begin{array}{l}\text { Cutting } \\
\text { depth } \\
(\mathrm{mm})\end{array}$} & $\begin{array}{c}\text { AISI } \\
304 \mathrm{SS}\end{array}$ & $\begin{array}{c}\mathrm{S} 45 \mathrm{C} \\
\mathrm{CS}\end{array}$ & $\begin{array}{l}\text { The } \\
\text { present } \\
\text { alloy }\end{array}$ \\
\hline & & & & & \multicolumn{3}{|c|}{ AMN of drilling holes } \\
\hline \multirow{4}{*}{ HSS } & $\phi 3$ & \multirow{4}{*}{3.46} & \multirow{4}{*}{0.185} & \multirow{4}{*}{15} & 38 & 48 & 30 \\
\hline & $\phi 6$ & & & & 30 & 42 & 25 \\
\hline & $\phi 9$ & & & & 22 & 34 & 16 \\
\hline & $\phi 12$ & & & & 13 & 18 & 6 \\
\hline \multirow{4}{*}{$\mathrm{HSS}-\mathrm{CN}$} & $\phi 3$ & \multirow{4}{*}{3.46} & \multirow{4}{*}{0.185} & \multirow{4}{*}{15} & 48 & 48 & 37 \\
\hline & $\phi 6$ & & & & 36 & 48 & 29 \\
\hline & $\phi 9$ & & & & 27 & 40 & 20 \\
\hline & $\phi 12$ & & & & 19 & 32 & 10 \\
\hline
\end{tabular}

$1200^{\circ} \mathrm{C}$ for $4 \mathrm{~h}$ in a protective argon atmosphere and hotforged into bars with a diameter of $40 \mathrm{~mm}$ and length of $100 \mathrm{~mm}$. Subsequently, the oxidation layers covering the bars were machined away. Before the tests, the bars were cut into smaller pieces that had a diameter of $40 \mathrm{~mm}$ and length of $25 \mathrm{~mm}$. They were then solution heat-treated at $1050^{\circ} \mathrm{C}$ for 40 min (quenched rapidly in water). Therefore, the specimens had a pure $\gamma$ phase structure at room temperature.

The drilling test was carried out on an upright drilling machine (MFG type, Tay Shing) using high-speed tool steel (HSS) and HSS-coated carbon nitride (HSS-CN) drills. The helix angle and lip angle of the drills were 32 and $118^{\circ}$, respectively. The drilling parameters are presented in Table 1. The average maximum number (AMN) of holes that could be created with 3-, 6-, 9- and 12-mm-diameter drills under suitable drilling conditions were determined in order to evaluate the drillability. Drilling tests were also performed on AISI 304 stainless steel (SS) and S45C carbon steel (CS) blocks with dimensions of $20 \times 20 \times 20 \mathrm{~mm}$ for comparison. The average of the values for five tests was used.

The microhardness measurements were made with a standardized Vickers microhardness tester (MVK-100, Akashi) using $300 \mathrm{~g}$ load and a dwell time of $10 \mathrm{~s}$. The average of the values obtained for ten tests was used. Moreover, the microstructural characteristics of the cut surface of each specimen were identified using a JEOL200CX transmission electron microscope (TEM) operated at $200 \mathrm{kV}$. Thin foils were polished to a thickness of around $40 \mu \mathrm{m}$, and subsequent electropolishing was performed using an electrolyte containing $60 \%$ ethanol, $30 \%$ nitric acid and $10 \%$ acetic acid at a current density of $(1.5-2.5) \times 10^{4} \mathrm{~A} / \mathrm{m}^{2}$ at temperatures less than $-10^{\circ} \mathrm{C}$. A thermal conductivity analysis was conducted using an infrared thermography device (TVS-100 series, Handy Thermo).

\section{Results and Discussion}

Figure 1 shows a bright-field (BF) electron micrograph of the alloy that had been solution-treated at $1050^{\circ} \mathrm{C}$ for $40 \mathrm{~min}$. The micrograph was recorded from the matrix in the [001] zone, indicating that some dislocations were formed in the matrix. A selected area electron diffraction pattern (SAEDP)

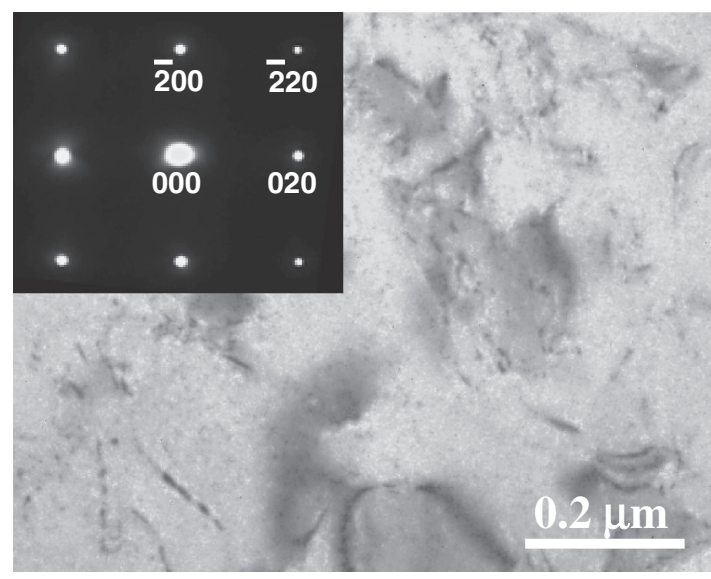

Fig. 1 BF electron micrograph of the alloy that had been solution-treated at $1050^{\circ} \mathrm{C}$ for $40 \mathrm{~min}$, which was taken from the matrix in the [001] zone.

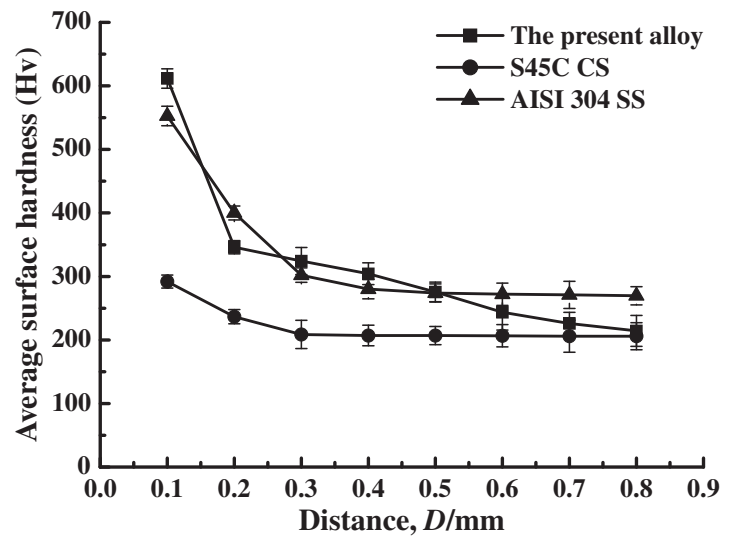

Fig. 2 The values of the average surface hardness near the holes in the investigated specimens drilled by the $9 \mathrm{~mm}$ HSS drill.

also revealed that the matrix has a single $\gamma$ phase and had a face-center-cubic structure with the lattice parameter $a=$ $0.375 \mathrm{~nm}$. No other precipitates were found within the $\gamma$ matrix of the as-quenched alloy. This microstructure is the same as that reported for an $\mathrm{Fe}-8.7 \mathrm{Al}-28.3 \mathrm{Mn}-1 \mathrm{C}-5.5 \mathrm{Cr}$ alloy by Liu et $a$. $^{1)}$

In the drilling tests, the AMN of holes that could be drilled in the alloys with various drill diameters is given in Table 1. The AMN of holes drilled in the S45C CS, AISI 304 SS and present alloy using the $3 \mathrm{~mm}$ HSS drill were 48, 38 and 30, respectively. The AMN decreased with an increase in the drill diameter. Only six holes could be drilled in the present alloy with a $12 \mathrm{~mm}$ HSS drill. Obviously, the drillability of the alloys when the HSS-CN drills were used was similar to that observed for the HSS drills. The AMN could be increased by around 4-10 holes by using the HSS-CN drills. The results significantly demonstrate that the Fe-8Al-30Mn-1C-1Si$3 \mathrm{Cr}$ alloy is more difficult to drill than AISI $304 \mathrm{SS}$ and S45C CS. Furthermore, it was found that the drill life when the drills were used on the present alloy was approximately 78.9 and $62.5 \%$ of that for AISI $304 \mathrm{SS}$ and S45C CS, respectively.

Figure 2 displays the values of the average surface hardness near the holes in the investigated specimens drilled by the $9 \mathrm{~mm}$ HSS drill. It was found that the present alloy had 
(a)

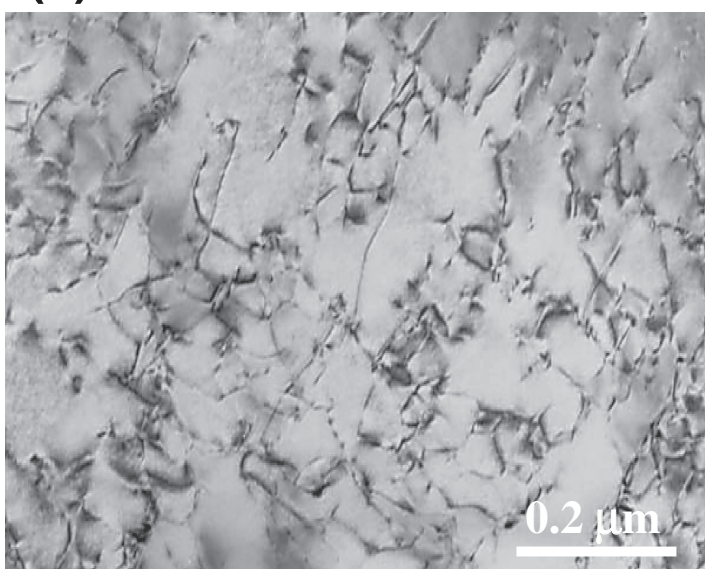

(c)

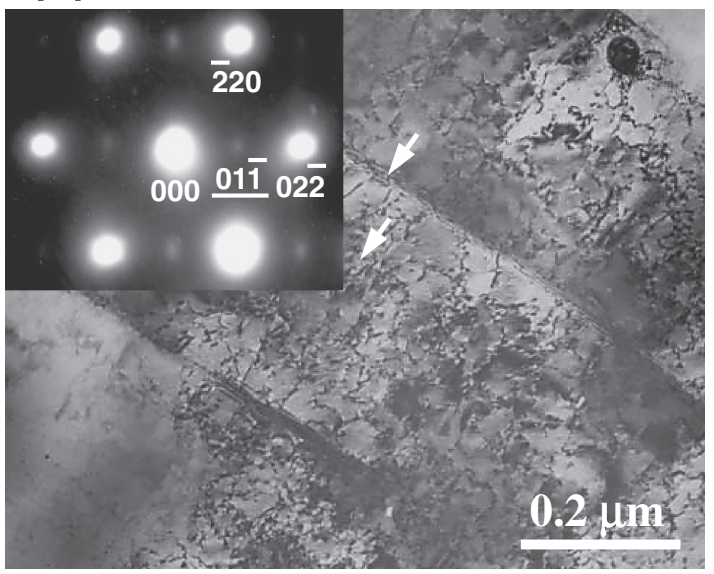

(b)

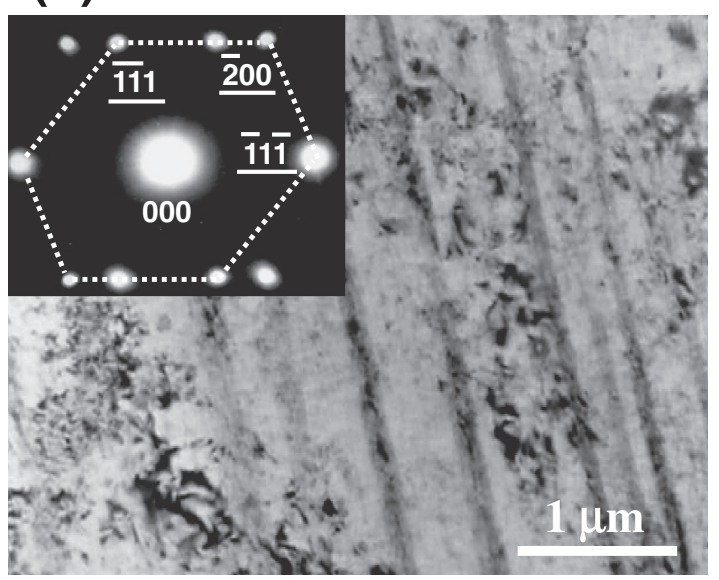

(d)

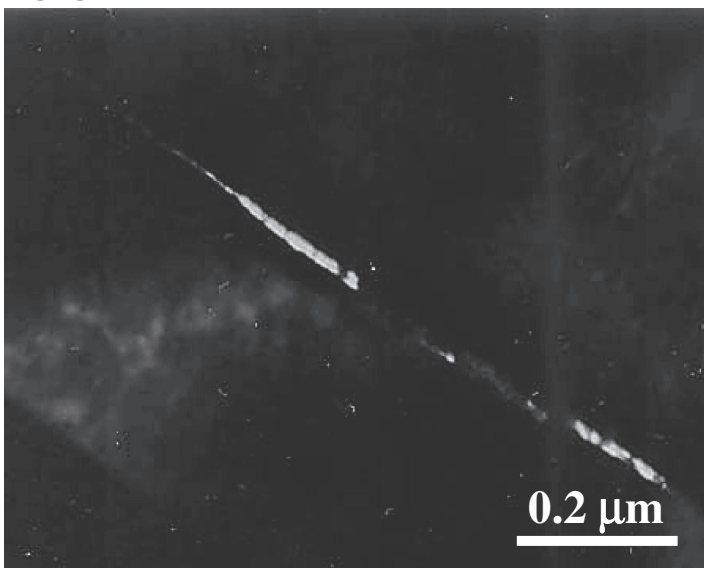

Fig. 3 TEM images taken from the hardened surface layer of the present alloy: (a) BF image showing a high density of dislocations; (b) BF image showing stress-induced twins (foil normal is [011]; $h k l=\gamma$ matrix); (c) higher magnification BF image taken from the stress-induced-twin boundary in the [111] zone ( $h k l=\kappa$ phase carbide, $h k l=\gamma$ matrix); and (d) $\vec{g}=01 \overline{1} \kappa$ phase DF image.

a $0.2 \mathrm{~mm}$ thick hardened surface layer, whereas $\mathrm{S} 45 \mathrm{C} \mathrm{CS}$ and AISI $304 \mathrm{SS}$ each had a layer that was $0.3 \mathrm{~mm}$ thick. Nevertheless, the Vickers hardness number $\left(\mathrm{H}_{\mathrm{V}}\right)$ of the layer on the present alloy, which was approximately 600, was higher than those of the layers on S45C CS or AISI 304 SS. In addition, we also found that in the present alloy, the drilled holes expanded by $0.02-0.05 \mathrm{~mm}$ in diameter. These features, namely, the hardened surface layer and the expansion of the holes were observed only in the alloy specimens drilled by 9 and $12 \mathrm{~mm}$ HSS-CN drills. As for the alloy specimens drilled using a drill with a smaller diameter $(<6 \mathrm{~mm})$, both the hardened surface layer and the increase in the hole sizes were not observed.

In order to elucidate the mechanism responsible for the difficulty encountered in machining the present alloy, the specimens with hardened surface layer were analyzed using TEM. Figure 3(a) is a BF electron micrograph of the hardened surface layer of the present alloy. It can be clearly seen that a large number of dislocations were formed in the layer. Moreover, Fig. 3(b), which is a foil normal [011] zone axis BF electron micrograph of the hardened surface layer of the present alloy, reveals that stress-induced-twins were also formed in the layer. ${ }^{20)}$ Furthermore, some small black particles (as indicated by the arrows) were found to have precipitated within the $\gamma$ matrix and stress-induced twin boundaries. Figure 3(c) is a magnified BF image of the stress-induced twin boundary along the [111] zone axis. It reveals that in addition to the reflection spots of the $\gamma$ phase, the SAEDP also comprises small superlattice spots. On the basis of the camera length and the $d$-spacings of the spots, we identified these small black particles as $\kappa$-phase carbides $\left((\mathrm{Fe}, \mathrm{Mn})_{3} \mathrm{AlC}_{x}\right)$ having an $\mathrm{L}^{\prime} 1_{2}$ structure with the lattice parameter $a=0.375 \mathrm{~nm} .{ }^{9,10,21,22)}$ Figure $3(\mathrm{~d})$ is a $\vec{g}=01 \overline{1} \kappa$ phase dark field (DF) electron micrograph that shows clearly the presence of the $\kappa$-phase within the $\gamma$ matrix and the stressinduced twin boundaries.

Some of the experimental results obtained are discussed in the following section. As mentioned above, the $\kappa$-phase carbides were noticed to have precipitated on the hardened surface layer of the present alloy. Many researchers have reported that the $\kappa$-phase carbides precipitate within the $\gamma$ matrices of $\mathrm{Fe}-\mathrm{Al}-\mathrm{Mn}-\mathrm{C}$ and $\mathrm{Fe}-\mathrm{Al}-\mathrm{Mn}-\mathrm{C}-\mathrm{X}$ alloys after aging at $450-750^{\circ} \mathrm{C} .^{3,4,23-25)}$ However, there have been no prior studies reporting $\kappa$-phase carbide precipitation by machining or any other material-working process. Thus, this implies that the heat produced during the cutting process (or "cutting heat") plays an important role in the formation of the $\kappa$-phase. In order to elucidate the formation mechanism of the $\kappa$-phase, thermal conductivity analyses of the present alloy and AISI 304 SS were performed. Figure 4 shows the 
(a)

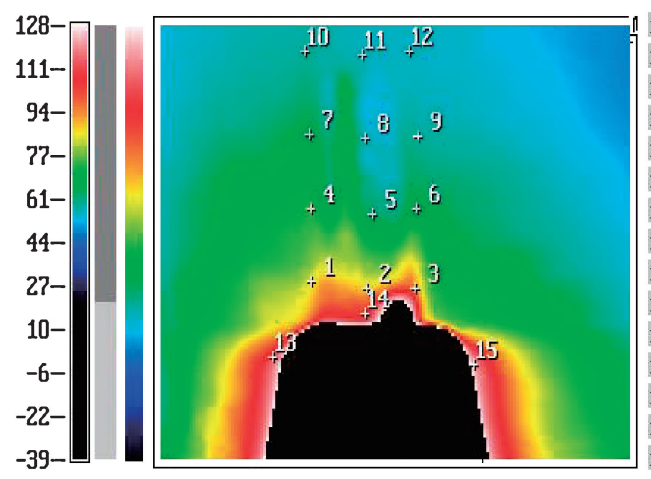

(b)

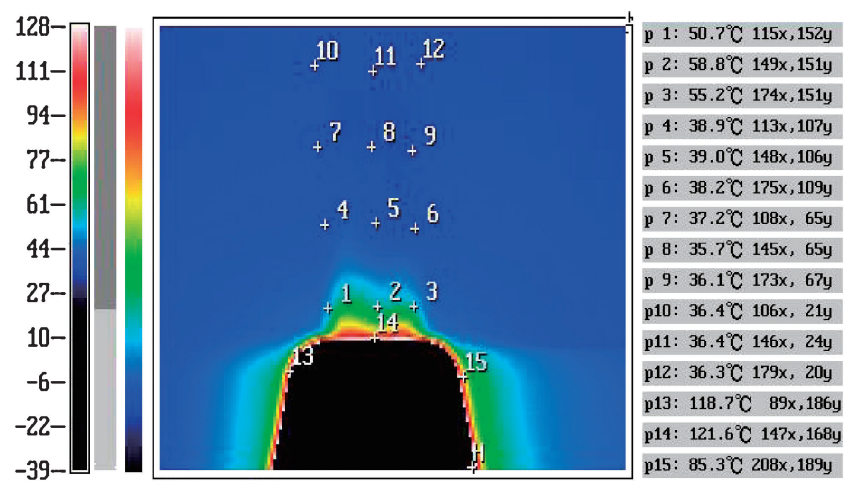

Fig. 4 Thermal distribution images of (a) AISI 304 SS and (b) the present alloy heated at $120^{\circ} \mathrm{C}$ for $5 \mathrm{~min}$.

thermal distribution images of AISI 304 SS and the present alloy; samples of both materials were heated at $120^{\circ} \mathrm{C}$ for $5 \mathrm{~min}$. It is clear that the surface temperature of the present alloy was lower than that of AISI 304 SS. The heat transfer coefficients of the present alloy and AISI 304 SS obtained from the infrared thermography device were 0.083 $\mathrm{cal} /\left(\mathrm{cm}^{2} \mathrm{~s}^{\circ} \mathrm{C}\right)$ and $0.098 \mathrm{cal} /\left(\mathrm{cm}^{2} \mathrm{~s}^{\circ} \mathrm{C}\right)$, respectively. These results reveal that the present alloy has slightly lower thermal conductivity. Therefore, the cutting heat produced between the nose of the tool and the cutting surface could easily have built up to a large value during the machining process. Moreover, we found that the instantaneous cutting temperature of the present alloy was approximately $650^{\circ} \mathrm{C}$, which is equivalent to the aging temperature. Hence, it can be reasonably deduced that the $\kappa$-phase carbides were formed within the surface hardening layer of the present alloy. Accordingly, a $\gamma \rightarrow(\gamma+\kappa)$ phase transition was observed in the matrix and at the stress-induced twin boundaries after the machining process. It is believed that the formation of $\kappa$-phase carbides not only decreases the drillability of the present alloy but also reduces the life of the cutting tool.

\section{Conclusions}

(1) The drill life with respect to the present alloy was approximately 78.9 and $62.5 \%$ of that for AISI 304 SS and $\mathrm{S} 45 \mathrm{C} \mathrm{CS}$, respectively. In addition, the present alloy had a $0.2 \mathrm{~mm}$ hardened surface layer and a Vickers hardness number $\left(\mathrm{H}_{\mathrm{V}}\right)$ approximately equal to 600 .
(2) A large number of dislocations, stress-induced twins and $\kappa$-phase carbides $\left((\mathrm{Fe}, \mathrm{Mn})_{3} \mathrm{AlC}_{x}\right)$ having an $\mathrm{L}^{\prime} 1_{2}$ structure with the lattice parameter $a=0.375 \mathrm{~nm}$ were formed within the surface hardening layer of the present alloy after the machining process.

(3) The heat transfer coefficients of the present alloy and AISI $304 \mathrm{SS}$ were found to be $0.083 \mathrm{cal} /\left(\mathrm{cm}^{2} \mathrm{~s}{ }^{\circ} \mathrm{C}\right)$ and $0.098 \mathrm{cal} /\left(\mathrm{cm}^{2} \mathrm{~s}{ }^{\circ} \mathrm{C}\right)$, respectively. The instantaneous cutting temperature was approximately $650^{\circ} \mathrm{C}$ for the present alloy.

\section{Acknowledgements}

The authors would like to thank the co-first author Hsi-Jen Chiang for his contribution in this research. The authors would also like to thank the Center of Excellence for Clinical Trial and Research in Neurology and Neurosurgery, Taipei Medical University-Wan Fang Hospital for financially supporting this research under contract No. DOH101-TD-B111-003, and supported partly by the Department of Health, Executive Yuan, Taiwan under contract No. DOH101-TDN-111-004.

\section{REFERENCES}

1) C. M. Liu, H. C. Cheng, C. Y. Chao and K. L. Ou: J. Alloy. Compd. 488 (2009) 52.

2) S. C. Chang, Y. H. Hsiau and M. T. Jahn: J. Mater. Sci. 24 (1989) 1117.

3) C. F. Huang, K. L. Ou, C. S. Chen and C. H. Wang: J. Alloy. Compd. 488 (2009) 246.

4) M. S. Chen, H. C. Cheng, C. F. Huang, C. Y. Chao, K. L. Ou and C. H. Yu: Mater. Charact. 61 (2010) 206.

5) C. S. Chen, C. T. Lin, P. W. Peng, M. S. Huang, K. L. Ou, L. H. Lin and C. H. Yu: J. Alloy. Compd. 493 (2010) 346.

6) Z. Sun, H. A. Davies and J. A. Whiteman: Metal Sci. 18 (1984) 459.

7) A. Inoue, Y. Kojima, T. Minemura and T. Masumoto: Metall. Mater. Trans. A 12 (1981) 1245.

8) S. K. Banerji: Metal Prog. 113 (1978) 59.

9) K. H. Han, W. K. Choo and D. E. Laughlin: Scr. Mater. 22 (1988) 1873.

10) K. Sato, K. Tagawa and Y. Inoue: Mater. Sci. Eng. A 111 (1989) 45.

11) V. D. F. C. Lins, M. A. Freitas and E. M. De Paula e Silva: Corros. Sci. 46 (2004) 1895.

12) Y. G. Kim, Y. S. Park and J. K. Han: Metall. Mater. Trans. A 16 (1985) 1689.

13) B. Bhattacharya, A. S. Sharma, S. S. Hazra and R. K. Ray: Metall. Mater. Trans. A 40 (2009) 1190.

14) I. Baker, R. K. Zheng, D. W. Saxey, S. Kuwano, M. W. Wittmann, J. A. Loudis, K. S. Prasad, Z. Liu, R. Marceau, P. R. Munroe and S. P. Ringer: Intermetallics 17 (2009) 886.

15) I. S. Kalashnikov, V. S. Litvinov, M. S. Khadyyev and L. D. Chumakova: Phys. Met. Metallogr. 57 (1984) 160.

16) P. J. James: J. Iron Steel Inst. 207 (1969) 54.

17) C. Y. Chao and C. H. Liu: Mater. Trans. 43 (2002) 2635

18) S. L. Chen, M. H. Lin, C. C. Chen and K. L. Ou: J. Alloy. Compd. 456 (2008) 413.

19) C. Y. Chao, S. H. Wu and H. M. Chung: Proc. Brunei Int. Conf. on Engineering Technology, Brunei, (2001) p. 565.

20) W. C. Cheng and H. Y. Lin: Mater. Sci. Eng. A 341 (2003) 106.

21) J. W. Lee and T. F. Liu: Mater. Chem. Phys. 69 (2001) 192.

22) C. H. Wang, M. S. Huang, C. W. Luo, K. L. Ou, H. C. Cheng and C. H. Yu: J. Alloy. Compd. 509 (2011) 691.

23) K. H. Han and W. K. Choo: Metall. Mater. Trans. A 14 (1983) 973.

24) K. Sato, K. Tagawa and Y. Inoue: Metall. Trans. A 21A (1990) 5.

25) I. S. Kalashnikov, O. Acselrad and A. Shalkevich: J. Mater. Process. Technol. 136 (2003) 72. 